\title{
Korea's Policy on Free Trade Agreements and its Position on an Agreement with Japan
}

\author{
Inkyo Cheong*
}

\begin{abstract}
The government of Korea considers the promotion of Free Trade Agreements (FTA) as necessary to develop its economy into an open trading nation. As for the countries with which the Korean government is actively investigating possible FTAs, there are Japan, Singapore, the Association of South East Asian Nations (ASEAN,) and Mexico. For the time-being, the FTA with Japan seems to be a critical one in practicing Korea's FTA policy. Recently, Korean industries show negative positions against a Korea-Japan FTA, with strong opposition from the labor union insisting that it is evident that Korea will sustain damages in the shortrun and the dynamic (long-term) benefits are still ambiguous and uncertain. Regardless of whether their argument is correct or not, it will be difficult for Korea to conclude the FTA with Japan unless there is concrete confidence of balanced economic gains through the FTA between the two countries.
\end{abstract}

Keywords: Free Trade Agreement (FTA), Economic Integration, Business Hub

\section{INTRODUCTION}

Korea concluded its first FTA with Chile October 2002 and the first FTA began to be implemented April 2004. The core issue for Korea's trade policy was the ratification of its FTA with Chile by the Korean National Assembly in early 2004. Farmers saw that the Korean government's promotion of FTAs would prove a further blow to the agricultural sector and as a result, the agricultural sector opposed the FTA with Chile for fear of the consequences of other FTA promotion in general (rather than a specific objection to a partnership with Chile). Korea has opened the agricultural market with the Korea-Chile FTA ratification, and hereafter, Korea's FTA promotion is expected to progress to encompass other economies.

The successful conclusion of the first FTA will be especially important to Korea, and other potential FTAs will heavily depend on the first model. Prior to launching its longterm goal of establishing FTAs with larger trade partners such as the US, Japan, China and the ASEAN Free Trade Area (AFTA), Korea needs to pursue FTAs with smaller partners in the short term. The experience will help the government to minimize risks and possible losses, as well as to be better prepared for the operation and negotiation of FTAs.

- Professor, Department of Economics, Inha University, 253 Yonghyun-dong, Nam-Ku Incheon 402751, Korea. E-mail: inkyo@inha.ac.kr. 
The ratification of the FTA with Chile is an epochal turning point for Korea's trade policy; herewith, Korea established a foothold to progressively cope with global proliferation and the deepening of regionalism. Moreover, it enables Korea to actively prepare for economic integration in the Asia-Pacific region through FTAs with major trade partners such as Japan, Mexico, ASEAN, the U.S., and China. The agreement is the first trade policy pursued and concluded by Korea on its own after the decision to use an FTA as a strategic trade policy, and not by means of multilateral trade liberalization such as the Uruguay Round (UR) or the DDA.

\section{KOREA'S POSITION TOWARDS FREE TRADE AGREEMENTS}

\section{Overviews}

Korea's new government (a participatory government), which started in February 2003, has made a policy that it would promote FTAs. After the inauguration of the new government, the new administration has set the goal of passing the Korea-Chile FTA and the FTA Implementation Act through the National Assembly at the earliest possible time. On July 2, President Roh Moo-hyun requested that the National Assembly ratify the free trade agreement made between Korea and Chile and pass other pending economic bills in a letter to National Assembly Speaker Park Kwan-yong.

Several reasons why the new government supports FTAs can be provided. Recently in Korea there has been a strong consensus that the government must deal with the spread of economic regionalism in the world. Korean newspapers have treated FTAs as major economic issues in articles, insisting that the participatory government should get the ratification of the Korea-Chile FTA from the National Assembly at the earliest time and promote more FTAs with other trading countries to embody Korea's image of openness and economic reforms. The major Korean newspapers have displayed concerns that the image of Korea as an open trading nation can be ruined if the government is not able to cope with domestic, anti-liberalization movements, and establish FTAs with major trading partners following the international trend of economic regionalization, which has speeded up since the official launch of the WTO.

Moreover, the WTO has indicated that trade among member countries of regional trade agreements constitute 43 per cent of the total global trading at the end of 2002 and will constitute 51 per cent by 2005 . If Korea fails to establish FTAs with other nations, it will lose its competitiveness because Korean products will be treated less favorably than those of FTA member countries. Economic integration in both the Americas and in Europe is also speeding up; the European Union will accept ten Eastern European countries by 2004 and is promoting FTAs with various regions such as Mediterranean countries and MERCOSUR of the South America. As for the Americas, the United States is taking the initiative of creating the Free Trade Area of the Americas (FTAA) by 2005 as the next agenda of the North America Free Trade Agreement (NAFTA). 
Meanwhile, Korea's participatory government considers the promotion of FTAs as necessary for Korea to develop into an open trading nation. President Rho insisted on actively dealing with the international trend of FTAs, while taking care of the sectors that will be damaged from the opening of markets. While some of the agricultural organizations are strongly against the approval of the Korea-Chile FTA, the general sentiment, such as that of the media, is that the Korean government should actively promote FTAs. However, after the Korea-Chile FTA was initially reached, only joint research groups of industrial, governmental and academic sectors were formed for bilateral FTAs with Japan and Singapore, without any additional negotiations with other countries.

Furthermore, it has been also inevitable for the government to pay attention to the fact that East Asian countries are actively promoting FTAs with other East Asian countries and with non-East Asian nations, which is different from the previous situation that discussion on FTA issues in East Asia had been inactive. The Japan-Singapore Economic Partnership Agreement (EPA) was reached in 2002. Also, China and the Association of South East Asian Nations (ASEAN) agreed on a framework agreement of a bilateral FTA in November 2002 and agreed to reach an FTA by June 2004. The Japanese government launched a committee to promote a Chosen Economic Partnership (CEP) with ASEAN. The member nations of ASEAN officially launched the Asian Free Trade Area (AFTA) in January 2002, and some of the ASEAN members such as Singapore and Thailand put their efforts into reaching bilateral FTAs with non-ASEAN countries, including Korea, China and the U.S. Furthermore, the East Asian countries $($ ASEAN+3) adopted the East Asia Study Group (EASG) report in November 2002, which supports the formation of the East Asia Free Trade Area (EAFTA).

One of backgrounds for Korean government's pursuit of FTAs can be related with a goal of the business hub of North East Asia. One of the new government's goals is to develop Korea into a business hub of North East Asia. It is to take advantage of Korea's geo-political position in North East Asia, to realize the potential economic gains from economic integration, to promote the development and identity of North East Asia, and to eventually develop the region into an economic union like the European Union (EU).

To achieve the goal of developing Korea into a business hub of North East Asia, there needs to be cooperation in various sectors, such as industries, finance, IT, energy, and environment. However, the inflow of foreign direct investment (FDI) through opening domestic markets and improving economic rules and systems is the most essential. Also, political stabilization and national security would be important factors for foreign investors. As we have seen in the cases of the Netherlands and Singapore, economic reform, and opening of markets and political stabilization are the first things that are needed in order to become a business hub. These pre-conditions for a business hub can be achieved through FTAs with neighboring countries. A China-Japan-Korea FTA, which officially and systemically promotes economic cooperation among the three countries, is also closely related to the establishment of a North East Asian business hub. Therefore, it is necessary for the government to consider Japan-Korea, China-Japan- 
Korea, and China-Korea FTAs. Although the trilateral FTA in the region should be realized in due time, there should be research and discussions on the issue from now on. Since the China-Japan-Korea FTA may be discussed at the summit among the three countries in October 2003, the Korean government should make it clear its stance on the Korea-China-Japan FTA before the meeting.

\section{Korea's Free Trade Agreements under either Negotiation or Discussion}

Korea had reached an FTA with Chile after the three-year negotiations. Besides this FTA, Korea has discussed FTAs with many other countries. First of all, Japan and Singapore are the nations with which the government is working on bilateral FTAs. As for Japan, there were six conferences regarding FTAs after the joint research group of industry, government and academia was lunched in July 2002. The Korean president and the Japanese prime minister agreed to start a negotiation on the Korea-Japan FTA in the near future at the Korea-Japan summit of June 2003. As for Singapore, the joint research group was lunched in March 2003 for a period of six months. Although discussions between the two countries have been delayed due to the SARS outbreak this year, there is a possibility that a negotiation will be initiated earlier than expected since there is no agricultural issue, which is a sensitive matter in Korea.

As for the countries with which the Korean government is actively investigating possible FTAs, there are Mexico, the ASEAN and Thailand. Since Mexico is a gateway to the North American market and has a great potential as a market for exports, Korean industrial sectors have strongly emphasized the importance of having an FTA with Mexico. The Mexican economy ranks $12^{\text {th }}$ in the world economy ( $\$ 481.4$ billion), which is 1.1 times of the Korean economy. Moreover, since Mexico currently holds FTAs with thirty-two countries, the disadvantages of Korean companies in Korea have been increasing. Therefore, there is a great need to promote a Korea-Mexico FTA. However, in November 2003, as Mexico declared a moratorium against further FTAs except an FTA with Japan, which was under negotiation, discussion for a bilateral FTA between two countries could not continue until Korean Trade Minister, Mr. Hwang, Doo-Hyun, met Mexican counter partner May 2004, to resume official dialogue for a bilateral FTA.

Korea is also investigating an FTA with the ASEAN. While the ASEAN proposed an ASEAN-Korean FTA at the ASEAN-Korea summit in November 2001 and 2002, the Korean government was not ready to accept ASEAN's proposal, although it has felt a the need to promote an FTA with ASEAN since a great amount of benefits are to be expected. However, due to a variety of economic systems and gaps in the development stage among the ASEAN members, it is expected that it would be difficult to initiate an FTA negotiation with ASEAN at an early time. In addition, since there are expected damages to the agricultural sector from entering into an FTA with ASEAN, it would be difficult for the Korean government to draw public support. However, in light of a situation that competitor countries of Korea such as Japan and China are actively seeking to reach bilateral FTAs with ASEAN, there would be great economic disadvantages for Korea if only Korea is excluded from an FTA with ASEAN. Both parties agreed to introduce a 
joint study group for studying a bilateral FTA at the end of 2003, and the first meeting was held in Jakarta, Indonesia, March 2004. The report by the study group will be reported to the ASEAN-Korea Leaders' Meeting (November 2004). Following current discussion on an FTA between ASEAN and Korea, it is expected that both parties should initiate official negotiation on a bilateral FTA in the near future.

It is also possible for the Korean government to promote FTAs with individual countries of ASEAN such as Thailand, the Philippines and Malaysia. As for Thailand, there have been two joint research meetings between the research institutes of the two countries in 2000, and the results of the research were exchanged in March 2001. However, the Korean government has postponed further discussions due to the delayed conclusion of the FTA with Chile. Thailand has had a position that an FTA should be promoted since the two countries' industries are complementary, and that it is willing to be flexible on sensitive issues for Korea. The Philippines has also suggested studying a Korea-Philippines FTA last year.

It is expected that Korea's participatory government will consider the China-JapanKorea FTA as a relatively important manner along with the Korea-Japan FTA. The three concerned countries - China, Japan and Korea - have agreed to study a trilateral FTA at the summit among the three countries in November 2002. At present, joint research groups on the economic effects of the China-Japan-Korea FTA are in the works by economic research institutes of the three countries (China's Development Research Center of the State Council (DRC), Japan's National Institute for Research Advancement (NIRA) and Korea Institute for International Economic Policy (KIEP)). The three countries constitute twenty per cent of the world's GDP and thirteen per cent of the world's trade. It is expected that the China-Japan-Korea FTA will bring great economic benefits to the three countries and contribute to the opening of North Korea and stabilization on the Korean peninsula. The Korean industries have insisted on the necessity of this FTA, and it is true that the importance is acknowledged in Korea in light of economic and strategic benefits. However, the three countries are not clearly motivated at this time, and Korea is greatly concerned about some aspects, such as trade liberalization for the agricultural sectors. 
Table 1. Current Progress of FTAs in Korea (2004)

\begin{tabular}{|c|c|c|c|}
\hline Stage & Region & Current Status & Remark \\
\hline Implementation & Chile & $\begin{array}{l}\text { Implementation } \\
\text { (April, 2004) }\end{array}$ & $\begin{array}{l}\text { Ratification by the National } \\
\text { Assembly is required }\end{array}$ \\
\hline \multirow{2}{*}{$\begin{array}{l}\text { Official } \\
\text { Negotiation }\end{array}$} & Japan & \multirow{2}{*}{ Official Negotiation } & $\begin{array}{l}\text { The fourth round of negotiation } \\
\text { (Tokyo, June 2004) }\end{array}$ \\
\hline & Singapore & & $\begin{array}{l}\text { The third round of negotiation } \\
\text { (Singapore, May 2004) }\end{array}$ \\
\hline \multirow{5}{*}{$\begin{array}{l}\text { Joint Research } \\
\text { or } \\
\text { Official } \\
\text { Discussion }\end{array}$} & ASEAN & $\begin{array}{l}\text { Joint Study Group of } \\
\text { Government, Academia, } \\
\text { and Business }\end{array}$ & $\begin{array}{l}\text { The final reported will be presented at } \\
\text { the ASEAN-Korea Leaders' Meeting } \\
\text { (Vientiane, Laos, November 2004) }\end{array}$ \\
\hline & Mexico & $\begin{array}{l}\text { Internal investigation by } \\
\text { each completed. }\end{array}$ & $\begin{array}{l}\text { The first official meeting was held } \\
\text { October } 2004\end{array}$ \\
\hline & Canada & \multirow{3}{*}{$\begin{array}{l}\text { Under internal } \\
\text { investigation }\end{array}$} & $\begin{array}{l}\text { A joint study group (2005) is expected } \\
\text { to be organized. }\end{array}$ \\
\hline & India & & $\begin{array}{l}\text { Introduction of a joint study group was } \\
\text { agreed October } 2004 \text {. }\end{array}$ \\
\hline & EFTA & & $\begin{array}{l}\text { A joint study group (2004) is under } \\
\text { operation. }\end{array}$ \\
\hline \multirow{2}{*}{$\begin{array}{l}\text { Possible Partner } \\
\text { Countries }\end{array}$} & U.S. & & Positive position of U.S. \\
\hline & China & & Korean industrial sectors requested \\
\hline \multirow[t]{2}{*}{ Others } & $\begin{array}{l}\text { China-Japan- } \\
\text { Korea }\end{array}$ & $\begin{array}{l}\text { Joint research by China } \\
\text { (DRC), Japan (NIRA), } \\
\text { Korea (KIEP) }\end{array}$ & $\begin{array}{l}\text { China proposed a joint research } \\
\text { (2002). }\end{array}$ \\
\hline & $\begin{array}{l}\text { East Asian } \\
\text { FTA }\end{array}$ & & Reports by EAVG and EASG \\
\hline
\end{tabular}

Note: EAVG-East Asian Vision Group, EASG-East Asian Study Group Source: Authors' Summary

It is analyzed that China has not shown intentions to promote official negotiations for a trilateral FTA of China-Japan-Korea in the governmental level at present. However, affiliated research institutes of the government have set forth research results that emphasize the positive effect of a China-Japan-Korean FTA. Meanwhile, the Japanese government states that it will prioritize the Korea-Japan FTA and investigate the FTA with China in the long term. In addition, the short-term promotion of an FTA with China will place a burden on Korea in a situation where Korea is not fully prepared for a complete market opening in the agriculture and manufacturing industry.

A bilateral FTA with the U.S. is also acknowledged to hold economic and strategic interests. The economic scale of the U.S. (GDP $\$ 10$ trillion) is twenty times greater than that of the Korean economy, and the U.S. is the number one trade partner of Korea (US\$53 billion). According to the research results on a Korea-U.S. FTA by the U.S. International Trade Center (ITC), it is expected that Korean exports to the U.S. will increase by twenty one per cent (US\$10 billion) and that U.S. exports to Korea will increase by fifty four per cent (US\$ 19 billion). The sectors where trade is expected to 
increase are textile, clothing, chemistry, and electronic products for Korea, and rice, meat, and dairy products for the U.S. However, in the light of passive attitude of the U.S. towards the FTA and the possible impact on the Korean agricultural sectors, it would be difficult to initiate a bilateral FTA in the short term. Recently, the U.S. and Korea show concern over a bilateral FTA. Senior trade policy makers of the U.S. Trade Representative Office gave positive comments on the FTA since May 2004, ${ }^{1}$ and Korea's Trade Minister stated that two countries need to review bilateral FTA, in an international conference titled as "Rising East Asian Regionalism and the U.S.-Korea FTA" held in Washington, D.C. October 2004.

The East Asian Free Trade Area (EAFTA) is one of the FTAs that Korea needs to investigate in the long term. The East Asian Study Group has submitted a report that encourages the EAFTA, and the leaders of the thirteen countries of ASEAN+3 adopted the report at the ASEAN+3 summit (at Cambodia) in November 2002. Although the importance of the EAFTA is fully acknowledged in terms of economic and strategic interests, it would be difficult to proceed in the short term due to the diversity among member countries in terms of economic systems and development stages.

\section{EVALUATION OF A JAPAN-KOREA FREE TRADE AGREEMENT}

\section{Korea's Perspectives on a Japan-Korea Free Trade Agreement}

In the domestic debate over an FTA with Japan in late 1998, the majority of the government, research and business sectors stated that it was premature to discuss such an agreement. Therefore, it was not easy to find experts that insisted that a Korea-Japan FTA should be considered in terms of promoting bilateral economic cooperation. Even researchers in charge of the study of Korean FTA policies at national think tanks such as KIEP opposed the possibility of an FTA with Japan.

At a bilateral summit meeting in November 1998, the political leaders of Japan and Korea agreed to analyze the possible economic impacts of a Korea-Japan FTA. As a result, researchers from KIEP and Japan's Institute for Developing Economies (IDE) carried out this research for two years, culminating in the release of a report that suggested that a Japan-Korea FTA is economically desirable under certain conditions. That is, although Korea may lose from the trade liberalization enabled through the FTA, such an agreement could provide significant dynamic gains to Korea by realizing economies of scale, enhancing the competitive business environment, increasing investment inflows and expanding strategic alliances among companies. Both institutes state that a Korea-Japan FTA could alleviate the pressures of industrial structure adjustment based on the understanding that there are differences in the structure of tariff rates and industrial

\footnotetext{
I In the past, the US did not prioritize the FTA with Korea, considering the delayed conclusion of a Bilateral Investment Treaty (BIT) and Korea's inflexible attitudes toward agriculture.

${ }^{2}$ Refer to KIEP and IDE (2000) for the joint study by KIEP and IDE on the economic effects of an FTA between Korea and Japan.
} 
competitiveness. ${ }^{2}$ However, the Ministry of Commerce, Industry and Energy (MOCIE) of Korea, representing manufacturing industries, still did not support the FTA, arguing that the government should accept the general opposition from businesses while worrying about the impacts an FTA would have on manufacturing.

In late 2001, at the Korean-Japanese summit meeting, leaders agreed to establish a Korea-Japan FTA Business Forum to facilitate exchanges over a bilateral FTA and deliver opinions in the business sector to the governments of both countries. In 2002, the leaders of businesses from both countries released a report based on the discussions of the Business Forum. The statement indicated support for the proposed Korea-Japan FTA and sought the immediate promotion of such an agreement. Major participants in the Forum were the Federation of Korea Industries (FKI) representing large businesses, the Korea Chamber of Commerce and Industry (KCCI) representing the small and medium-sized enterprises (SMEs) and executives from conglomerates (chaebols) such as Samsung, LG, Hyundai and SK. The Forum submitted its report to the governments of Korea and Japan, strongly recommending the promotion of a bilateral FTA between two countries.

In Korea, a number of manufacturing SMEs that are producing parts and materials are expected to suffer losses from the FTA. Therefore, scores of SMEs have taken a negative position to the proposed FTA with Japan. However, the KCCI, an SME representative, played a leading role in preparing the final report, supporting an FTA with Japan. FKI also supported the FTA at the Forum. Regardless, its member companies were not very supportive of the FTA, as can be seen in a survey undertaken by FKI (2001). According to the survey, in Korea, the economic necessity for concluding FTAs is widely recognized by business, but there has been some opposition from some industrial sectors; some 88.3 per cent of respondents mentioned that FTAs should be actively promoted, an indication that many companies view FTAs positively.

Figure 1. Favored FTA Candidates for Korea

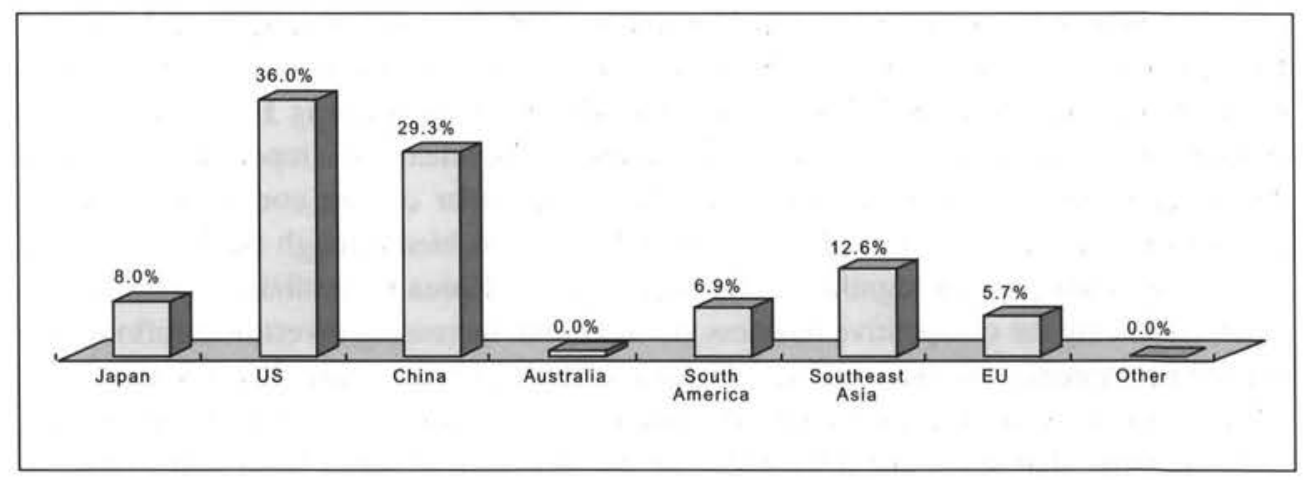

According to respondents, the United States and China are seen as the most favorable countries to become Korea's FTA partners (at 36.8 per cent and 29.3 per cent, respectively). Ironically, the Japan-Korea FTA, under negotiation now, was favored by 
only 8.0 per cent of respondents. Moreover, although there was only weak support from industries in concluding a Korea-Japan FTA, representatives from Korean industries adopted the pro-FTA report through the Forum. It was also contradictory that the KCCI drew up the draft of the final report for the Forum.

A lot of companies are skeptical as to whether the FTA has the potential to increase Korean exports to Japan because Japanese industries are more competitive; Japanese average tariff rates are as low as 2.7 per cent (Korean 7.8 per cent), and there are still nontariff barriers that cannot be eliminated through an FTA. Moreover, they argue that Korean imports from Japan will increase on a large scale. Examining the impacts of trade liberalization under the FTA on Korean industries, clothing, agriculture and processed food, textiles and fiber are potential beneficiaries. There will be no significant effects on iron and steel, semi-conductors and shipbuilding. Nevertheless, it is expected that an FTA would be disadvantageous for automobiles, machineries and household electronic appliances.

Although the government of Korea sees its industries as losers in bilateral trade liberalization through an FTA, it evaluates the FTA to be advantageous to Korean industries for the following reasons. First of all, the FTA could facilitate structural adjustment for Korean industries, which will be beneficial to Korea in the long-term, although it can bring in adjustment pains in the short run. Korea has introduced various policies for structural adjustment during last decades but has not seen satisfactory outcome so far. While there is no sign that the problem of overlapping and excessive investments will be resolved in the near future, competition between Korean and Japanese companies for overseas markets continues to intensify. The growing competition for the U.S. market can be clearly seen in the export similarity index. The export similarity index between Korea and Japan from 1995 to 2003 shows that Korea is not differentiating its products from Japanese goods, resulting in prolonged bilateral competition. In addition, the competition between Korea and China is increasing. In order to maintain market shares in major importing countries, Korean companies have reduced the prices for exporting goods and thus Korea's terms of trade have deteriorated so far, as seen in Figure 2.

Figure 2. The Trend of Korea's Commodity Terms of Trade

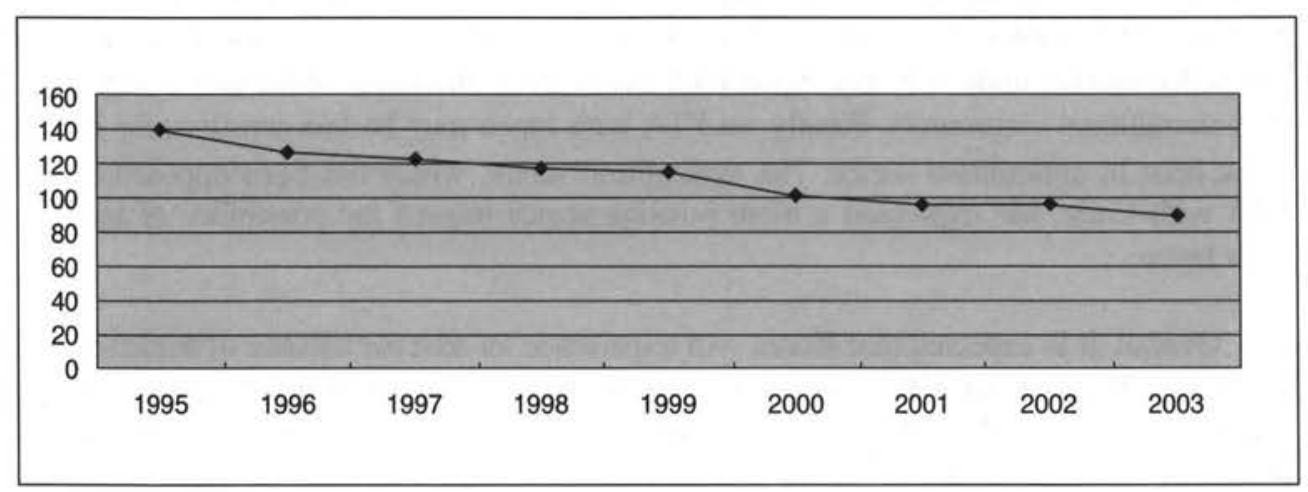

Source: MOCIE (2004). 
Another rationale for a Korea-Japan FTA is that trade liberalization under the FTA can force Korean companies to improve their international competitiveness. With the accession of China to the WTO at the Doha Ministerial Meeting in November 2001, China is in a position to gain increased international recognition as well as rapid economic growth. China's economic growth is creating business opportunities in China for Korean companies, but it can be regarded as threat for them in the near future, as China is catching up with Korea rapidly. Booz, Allen and Hamilton (1997) warned that Korea could be trapped in a "nutcracker" - caught between China's low costs and Japan's technical excellence. They state that "Korea is too small to compete directly with either Japan or China over the long term in its core industries," suggesting that market size be expanded by establishing FTAs with major trading partners.

A Korea-Japan FTA is expected to influence Northeast Asian economic integration in the long run. Given the recent discussions on a Northeast Asian FTA, consisting of China, Japan and Korea, as well as an East Asian FTA, both Korea and Japan would like to conclude a bilateral FTA first and then branch out to larger regional FTAs based on that experience. Following the proposal by then-Chinese premier Zhu Rongii, the economic feasibility of China-Japan-Korea (CJK) FTA is being officially studied in 2003-2005 by the Trilateral Joint Research Project of the DRC in China, the NIRA in Japan and KIEP in Korea. The three research institutes, representing their respective countries, have jointly studied how to strengthen economic cooperation in Northeast Asia since 2001. Last year, the joint study group presented to the political leaders of the three countries a summary report of the research topic for 2003 entitled "Economic Effects of Possible Free Trade Area among China, Japan and Korea (CJK)." Considering current internal and external conditions, a CJK FTA will be feasible in the mid to long term. However, the progress of a Korea-Japan FTA will encourage China to be more positive toward economic integration in the Northeast Asia. Thus, it can be said that a Korea-Japan FTA will contribute to the progress of a CJK FTA.

A Korea-Japan FTA would strengthen the two countries' international recognition. According to Bergsten (2000), East Asian countries have been neglected by international organizations like the IMF and IBRD. For example, although Japan's economy of scale is half those of the United States and Europe, respectively, its quota in these organizations is only one third and one fifth of the quotas of the United States and Europe, respectively. Korea, which ranks $11^{\text {th }}$ in terms of economy of scale, has a very small quota. An integrated market under a Korea-Japan FTA may elevate the status of the two countries in the international community. Finally, an FTA with Japan may be less sensitive for Korea - at least in agricultural sector. The agricultural sector, which has been opposed to the FTA with Chile, has expressed a more positive stance toward the possibility of an FTA with Japan.

Overall, it is expected that Korea will experience an adverse balance of trade toward Japan in a Korea-Japan FTA. However, with an adjusted industrial structure, technology transfer and the removal of non-tariff barriers in Japan, it can be a win-win FTA and the industrial competitiveness of Korea will be enhanced. Based on this, the government of 
Korea officially decided to negotiate an FTA with Japan in August 2003.

\section{Economic Effects of a Japan-Korea Free Trade Agreement}

In general, regional economic integration could be characterized as a process that reduces the significance of a country's trade policy within a specific region. It is being implemented mainly by reducing or abolishing tariff and non-tariff barrier. However, generally, these liberalization measures do not extend to non-member countries.

Economic integration could be classified into various stages according to its intensity: sectoral preferential agreements, free trade agreements, a customs union, a common market and an economic union. Regional economic integration was popularized in Europe during the 1950s. The Treaty of Rome, which gave birth to the EEC in 1957, is a good example. FTA, one of the forms of regional economic integration, is normally introduced in the aim of enhancing the national economic welfare. It is attained by reducing trade barriers and expanding intra-regional market, thus accomplishing economies of scale and pursuing economic gains from trade expansion.

Sectoral preferential trade agreements such as the European Coal and Steel Community Treaty in the early 1950s and North America's Auto Pact in the 1960s loosen restrictions on trade of specific products or sectors. They are, therefore, generally witnessed in the early stages of economic integration. In FTA, tariff and non-tariff barriers are preferentially reduced or abolished for the trade of products and services among member economies, while these countries maintain their own independent trade policies towards the non-member countries.

FTA enables the member countries to gain economic efficiency and more income since it abolishes trade barriers within the region thus increasing trade volume, promoting the division of labor and enhancing the efficiency of resource allocation. Economies of scale based on the comparative advantage of each member country reduce unit costs of products and enhance international competitiveness. These produce trade creation effects, which increase the economic gains of member countries. However, changes in the price competitiveness due to discriminatory tariff treatment between member countries and non-member countries can also reduce trade volumes with non-member countries, giving negative effects on the economic gains of member countries. This is called the trade diversion effect. It diverts the import sources from more efficient goods of non-member countries to less efficient goods of member countries. Therefore, in order to for an FTA to become economically feasible, trade creation effects should be maximized while trade diversion effects be minimized.

There are two major ways to estimate the effects of the formation of an FTA: static and dynamic analysis. Generally, static analysis compares the relative amounts of positive trade creation effects with negative trade diversion effects. In the static analysis, the benefits of economic integration increase when the industry and trade structures of the member countries are in complementary relationship. On the other hand, the economic 
gains of the integration decrease when they are in competitive relations. Despite the complementary relations of the industrial structure, specific products could compete one another under the intra-industry trade. Thus, analyzing the effects of economic integration requires prudent assessment. Korea and Japan have similar industrial structure in the area of manufacturing industries, and their products are mostly in competitive relations. ${ }^{3}$ This may reduce the benefits of economic integration from the static analysis.

But in the dynamic aspect, the benefits of the economic integration could be enlarged in the competitive relationship of industry and trade structure. This is due to the economies of scale resulted from enlarged markets, the improvement of production capacity resulted from the inflow of foreign direct investment, the advancement of productivity based on the transfer of technology, and the overall enhancement of economic efficiency through the creation of pro-competitive trade environment. Dynamic effects also help attaining economies of scale since producers have chances for mass production through specialization and enhanced division of labor within member countries of regional economic integration. Reduction or abolishment of various trade barriers within the member countries enhances competition among the producers and eliminates excessive profits, which are feasible under imperfect competition, which in turn improves economic efficiency. In response to the severe competition, each producer increases investment in technological development and renovation, which contributes to lowering production costs and improves the quality of their products. Moreover, it improves industrial cooperation and alliances between the industries in the region. It strengthens cooperation of intra-regional corporations that produces the same items, and, furthermore, helps them to produce new products and create new market or demand by establishing efficient channels such as joint technology investment and joint marketing.

Trade barriers such as tariffs play an important role in economic integration since the static effect of an FTA is usually generated from the changes in trade pattern. Korea, with its high tariff rates, is expected to suffer economic losses by abolishing tariffs for imports from Japan under a bilateral FTA. However, Korea can anticipate getting compensated most of the losses from tariff abolishment if Japan reduces its non-tariff barriers. On the other hand, the dynamic effects are highly related to the extent how much each member country improves its trade system and investment environment. Therefore, it can be said that the effects of an FTA can vary greatly depending on the position of each member country.

An FTA with Japan will cause structural adjustments for Korean industries, especially small and medium-sized companies, which could have been in business with the imposition of tariffs. In spite of economic gains for the whole economy, these companies will be closed and temporarily, workers will be unemployed and it will take

3 Unlike Koreans' general perception that trade structure between Korea and Japan is similar in composition, Kimura and Ando (2003) assert that trade liberalization in the bilateral FTA between Korea and Japan will not cause head-to-head competition, with their empirical finding that large portion of bilateral trade is one-way trade and vertical intra-industry trade. 
time and resources for them to have jobs in other industries. Most macro-econometrics models including CGE models do not consider industrial adjustment costs in assessing an FTA economically. If this cost is taken into consideration, the economic gains from an FTA will be smaller than the estimates from economic models.

\section{Gravity Model Approach}

Quantitative analyses on the economic effects of a Korea-Japan FTA have mostly been carried out through CGE Models and gravity models. After being largely used in evaluating the effects of NAFTA in the late 1980s, CGE Model has been widely used in the FTA quantitative analysis. It was introduced in Korea in the early 1990 s and is being largely used in evaluating trade policy since mid-1990s. Gravity model became popular since Krugman, Frankel and his colleagues used it for their studies in the 1990s, and in Korea it has become widely used by KIEP research fellows since 2001. Researches on evaluating the economic effects of a Korea-Japan FTA using gravity model include those by Sohn and Yoon (2001), Kim (2002) and Lee and Park (2002). In research by Sohn and Yoon (2001), potential trade volumes between Korea and its top 30 trade partner countries have been evaluated by using gravity models, including the trade conformity index and APEC dummy variables in the equation system. FTA partners have been selected through comparing these estimated trade volume and actual trade volume. According to the research, Japan - along with Thailand and Mexico has been selected as one of the five trade partners that have the lowest ratio of actual to potential trade volume. Korea's trade volume with Japan in 1995 was US\$46.9 billion whereas potential trade volume was $\$ 70.1$ billion, producing a ratio of mere 67 per cent. It was suggested that Korea's Import Source Diversification Program (abolished in 1999) and Japan's non-tariff barriers such as complex marketing channels and business practices were responsible for inactive bilateral trade. Therefore, if these non-tariff barriers are reduced through a Korea-Japan FTA, Korea's trade with Japan is expected to increase.

Kim's paper (2002) focuses on the analysis of trade structure of ASEAN+3 (China, Japan, Korea) member countries, and his gravity model introduces dummy variables of ASEAN, China-ASEAN, Japan-ASEAN and Korea-ASEAN. This has also estimated the ratio of actual to potential trade volume, which has increased from 0.08 (1990) to 1.26 (1999) in China-Korea trade, showing over-traded results. On the other hand, the ratio was 0.46 (1999) in Korea-Japan trade, marking the lowest record among the 13 member countries of ASEAN+3.

Table 2. The Ratio of Actual to Fitted Trade Flows in China, Japan and Korea

\begin{tabular}{l|c|c|c|c|c}
\hline & $\mathbf{1 9 8 0}$ & $\mathbf{1 9 8 5}$ & $\mathbf{1 9 9 0}$ & $\mathbf{1 9 9 5}$ & $\mathbf{1 9 9 9}$ \\
\hline \hline China-Korea & n/a & n/a & 0.08 & 1.18 & 1.26 \\
China-Japan & 1.09 & 1.58 & 1.60 & 1.25 & 1.22 \\
Japan-Korea & 0.54 & 0.40 & 0.57 & 0.32 & 0.46 \\
\hline
\end{tabular}

Source: Kim (2002) 
Lee and Park (2002) used Frankel et al (1997)'s gravity model with a tariff variable and dummy variables for imaginary trading blocs in order to capture the intra-regional trade bias of a hypothesized trading region. They estimated gravity trade volumes between pairs of countries in East Asia based on the income levels and distances, and checked whether the intra-regional trade bias (the differences between the performed trade volume and the gravity trade volume) is statistically significant or not. This is a typical analysis of a natural trading bloc. They found that a regional trading bloc among the Northeast Asian countries is not naturally forming. Similarly, they showed that there is no "tendency toward a special trade bias in the three possible combinations of regional groupings in the Northeast Asia, including Japan-Korea." That is, trade performances of these countries can be explained with the gravity model. This result contrasts with those of Kim (2002) and Sohn and Yoon (2001).

Kim (2002) and Lee and Park (2002) did not provide any reason for this contrasting finding, although economic models produce different results on a specific policy issue. In order to explain the discrepancy of contradictory results, it is necessary to compare and look into the models used in each research. These researches used gravity model in common and have equally adopted GDP, physical distances and various forms of dummy variables. However, along with these common variables, they have devised different gravity models by using some different variables. Sohn and Yoon (2001) has additionally adopted trade conformity index and APEC dummy variables, and Kim (2002) has used the product of per capita GDP of the countries and grouping dummy variables, while Lee and Park (2002) manipulated tariff rates, languages and bloc variables in their equation.

Discrepancies in the results of researches could be explained by selecting different models. The researchers did not explain how adding different additional variables could influence the estimated results. The gravity model itself can be a problematic factor too. This research, as well as others that used gravity models, do not provide discussion on the correlation problem between variables used in the model. Neither do they explain the appropriateness of the variables adopted in their model. The contrasting results can be also derived from the database used in the model. The measurement unit (kilometer, mile) for physical distance is an example. In short, gravity model can be one of the means to carry out empirical assessment on the economic feasibility of forming an FTA, however, the inherent problems in the process of formulating the model itself cannot be out of question.

\section{CGE Model Approach ${ }^{4}$}

\section{The Joint Study by KIEP and IDE}

The Korea Institute for International Economic Policy (KIEP) and Japan's Institute of Developing Economies (IDE) conducted a joint study on the economic impact of the

\footnotetext{
4 This section heavily depends on Cheong (2001).
} 
Korea-Japan FTA from 1999 to 2000. Although those institutes were supposed to produce a joint report on the issue, they underwent independent study and exchanged study results in 2000 .

KIEP's study results may be summarized as follows: (a) preferential tariff elimination between Japan and Korea may worsen Korea's welfare level and its trade balance with Japan; (b) a bilateral FTA may have a deep impact on Korea's heavy and chemical industry and worsen Korea's industrial structure; (c) in the case of an increase in foreign direct investment inflows under a bilateral FTA, Korea's total trade balance may improve substantially.

The forecast that Korea's welfare losses under an FTA with Japan can be found in Scollay and Gilbert (2001). However, studies conducted by other institutions show different results. While KIEP estimates that tariff elimination will cause Korea's welfare level to fall, Korea Institute for Industrial Economics and Trade (KIET) and Japan's IDE report opposite findings. With regards to effects on GDP, KIET and BDS (Brown, Deardorff and Stern 2000) offer similar results to the KIEP study, but IDE derived conflicting results. One common conclusion shared by all the studies is that Korea's trade balance will worsen under a bilateral FTA.

Table 3. Economic Impact of Korea-Japan Tariff Elimination (Static Effects)

\begin{tabular}{l|l|c|c|c|c}
\hline & & KIEP & IDE & KIET & BDS \\
\hline \hline \multirow{4}{*}{ Korea } & Welfare level (\%) & -0.19 & 0.34 & 0.48 & - \\
\cline { 2 - 6 } & GDP $(\%)$ & -0.07 & 0.06 & -0.07 & -0.23 \\
\cline { 2 - 6 } & Trade balance with Japan (\$100 million) & -60.90 & -38.85 & -33.60 & - \\
\cline { 2 - 6 } & Total trade balance (\$100 million) & -15.43 & -2.7 & -6.90 & - \\
\hline \multirow{3}{*}{ Japan } & Welfare level $(\%)$ & 0.14 & 0.03 & - & - \\
\cline { 2 - 6 } & GDP $(\%)$ & 0.04 & 0.00 & - & 0.18 \\
\cline { 2 - 6 } & Trade balance with Korea (\$100 million) & 60.90 & 38.85 & - & - \\
\cline { 2 - 6 } & Total trade balance (\$100 million) & - & 54.79 & - & - \\
\hline
\end{tabular}

Source: Cheong (2001)

The conflicting study results are attributed to differences in model structures, simulation methods, levels of shock of trade liberalization and the selection of data. While KIEP, IDE, and BDS used the CGE model, which includes multi-regions and multisectors, KIET's study relied on a single country model that only considered Korea. The CGE model has similar structures but there are slight differences in production structure. In other words, while the KIEP and BDS models assumed a Leontief-style fixed coefficient at the top of the production structure, the model used in IDE's study laid down a CES production function.

The sectors and databases used in the studies also slightly differed, with IDE and BDS focusing on tariff elimination in the agriculture, manufacturing, and service sectors, 
while KIEP excluded the service sector altogether. While KIEP, IDE and BDS all chose the fourth edition of Global Trade Analysis Project, which uses 1995 as its standard year, ${ }^{5}$ KIET's research team established its own database using Korea's 1995 Input Output table and trade data.

Differences could also be found in assumptions about movement of capital. The KIEP and BDS studies assumed an incomplete allocation scheme where the changes in world capital volume are distributed across the region by the same rate as the standard year, whereas IDE's study used a complete distribution method that allocates changes in capital volume by region in the short term based on the rate of return on capital.

It is difficult to explain the effects of the differences in the simulations on the models' results. If one model were used and different factors assumed, then a comparison of results would clearly show a causal relationship. However, this is not possible since all of the studies used different models. The reasons for the differences in findings can be inferred from the model used in KIEP's study. Generally, a complete allocation scheme of capital has a tendency to improve estimated results. For example, if Korea's trade balance worsens because of a Korea-Japan FTA, the welfare and income levels are estimated to be much higher under a complete allocation scheme that assumes rapid foreign direct investment inflows than an incomplete allocation scheme. The inclusion of liberalization in the service sector may also increase Korea's benefits. The service sector tariff used in the Japanese study was 0.32 per cent for Korea, while the rate for Japan was 3.23 per cent, thus giving Korea the upper hand in regard to services sector tariffs. ${ }^{6}$

An increase in productivity is also expected under a Korea-Japan FTA and the KIEP and IDE studies on the economic impact of such an increase both show similar results. In light of improved productivity under a bilateral FTA, Korea's welfare level is expected to increase by 7-11 per cent and GDP by 3-9 per cent. Any differences in estimated figures can be attributed to the assumption of increased productivity. In short, KIEP's study has assumed that foreign investment in Korea (including from Japan) would annually increase by $\$ 2.5-3.5$ billion with the elimination of tariff and non-tariff barriers under a KoreaJapan FTA. On the other hand, IDE's study assumed that Korea's productivity would increase 10-30 per cent during a 10-year period according to industry. The dollar figures estimated by KIEP were based on various FDI statistics and existing study results such as past foreign direct investment trends and Japan's total investment volume. IDE also provided the grounds for estimating a productivity increase of 10-30 per cent. But many people question the validity of both KIEP and IDE estimates.

\footnotetext{
5 Refer to Hertel et al. $(1998,2001)$ for information on the GTAP database.

6 Refer to Nakajima and Kwon (2001) for the industry tariff rates used in the IDE study.
} 
Table 4. Economic Impact of Korea-Japan Tariff Elimination (Productivity Growth)

\begin{tabular}{|c|c|c|c|c|}
\hline & & KIEP & IDE & Notes \\
\hline \multirow[t]{4}{*}{ Korea } & Welfare level (\%) & 11.43 & 7.09 & \multirow{4}{*}{$\begin{array}{l}\text { - increased manufacturing } \\
\text { productivity of an annual } 1 \\
\text { per cent during a 10-year } \\
\text { period }\end{array}$} \\
\hline & GDP (\%) & 2.88 & 8.67 & \\
\hline & $\begin{array}{l}\text { Trade balance } \\
\text { with Japan } \\
\text { (\$100 million) }\end{array}$ & -4.40 & -24.60 & \\
\hline & $\begin{array}{l}\text { World trade balance } \\
(\$ 100 \text { million })\end{array}$ & 30.14 & 408.00 & \\
\hline \multirow[t]{4}{*}{ Japan } & Welfare level (\%) & - & 9.29 & \multirow{4}{*}{$\begin{array}{l}-10 \text { per cent increased } \\
\text { productivity: textiles, } \\
\text { manufacturing, services } \\
-30 \text { per cent increased } \\
\text { productivity: metals, } \\
\text { transportation equipment, } \\
\text { electronics, machinery }\end{array}$} \\
\hline & GDP $(\%)$ & - & 10.44 & \\
\hline & $\begin{array}{l}\text { Trade balance } \\
\text { with Korea } \\
\text { (\$100 million) }\end{array}$ & - & 24.60 & \\
\hline & $\begin{array}{l}\text { World trade balance } \\
\text { ( } \$ 100 \text { million) }\end{array}$ & - & 182.00 & \\
\hline
\end{tabular}

Source: Cheong (2001)

\section{Problems in the Joint Study}

As examined in the previous section, while the findings of the majority of studies on the economic impact of a Korea-Japan FTA are similar to KIEP's, there is a significant difference from the results of IDE's study. The varying analyses stem from differences in model characteristics, scope of analysis, simulation shock and assumptions on international capital.

One of the problems in existing studies is that the selected models assume that economic activity conducted by regional economic agents all follow an identical decisionmaking process. In other words, the same parameters are applied to all regions included in the model, and therefore characteristics of individual economies are not well reflected. For example, because the 2.8 price elasticity of domestic and imported steel (Armington coefficient) is equally applied to Korea, Japan and other regions included in the model, differences in preference between domestic and imported steel are not reflected in the simulation. While modeling all of the characteristics of regional economies may be difficult, a model reflecting the economic characteristics of Korea should at least be used.

The tariff rate used for simulation shock also present a problem. Existing studies analyze the impact of bilateral tariff elimination using the tariff rates of the GTAP database, and thus are unable to indicate the effects on non-tariff and services liberalization. While the studies conducted by IDE and Brown, Deardoff and Stern (2001) analyze the effects of liberalization in services, they only refer to the results and not the specific content. Using the tariff rates of the GTAP database may also hurt the reliability of simulation estimates. Attention is especially needed in analyzing the current GTAP 
tariff rate for agriculture. In the case of a low bilateral share of trade for a certain commodity, calculating tariff rates by simply dividing tariff revenue by commodity by total imports may result in a tariff rate different from the applied tariff rate. If a few select commodities with high tariff rates within an industry are imported from a certain country, the average applied tariff rates may be much higher than general tariff rates. Should the distorted tariff rates be applied in the simulation, it may result in an overestimation in the selected industry.

Another problem is the selection of models. Existing studies use the perfect competition model; however, this model does not reflect economies of scale and promotion of competition and can result in an underestimation of the economic impact arising from an FTA. In particular, since the core industries of Korea and Japan have greater economies of scale, more focus should be given to the impact created by such a characteristic. The effect of capital accumulation was also not well reflected in existing studies due to the exogenous savings rate and capital volume.

\section{Dynamic Effects}

The simulation problems in the joint study suggest that the economic impact of a Korea-Japan FTA will be limited. There are a couple studies trying to estimate the effects of a Korea-Japan FTA using a full-dynamic CGE model (Mckibbin, Lee and Cheong, 2002) or a CGE model with internal decision mechanism for investment (Cheong, 2001).

Mckibbin, Lee and Cheong (2002) attempts to estimate the effects of a Korea-Japan FTA based on a new simulation model which is better equipped in assessing the dynamic effects of policy changes such as trade liberalization. Their experiments are based on a dynamic intertemporal general equilibrium model called the Asia-Pacific G-cubed Model. Their model has a number of advantages over the standard CGE models. Unlike the standard CGE models, this model permits an incorporation of rational expectations and forward-looking intertemporal behavior on the part of individual agents.

Bilateral elimination of tariffs in Korea and Japan is expected to lead to a reallocation of resources in both countries. In the long run, the reallocation of resources raises incomes in both countries. In the short run there are adjustment costs, which reduce the short run income gains relative to the long run gains. The real GDP gain amounts to about 0.15 percentage points relative to the baseline by 2020. An interesting result they find is that the output gains are greater when the tariff cuts are phased out than when tariffs are eliminated at once. This result holds true in both Korea and Japan. Finally, the exclusion of agriculture from the FTA reduces the GDP and consumption gains for both countries, with bigger losses for Korea. This is not surprising given that protecting agriculture sector implies inefficient allocation of production resources.

Cheong (2001) attempted to improve 2000 KIEP's estimates using a Baldwin (1989)type CGE model with capital accumulation mechanism. ${ }^{7}$ The purpose of his study was to provide more accurate estimates of a Korea-Japan FTA for Korea, and his works were 
focused on Korean side modeling. The CGE model used in Cheong (2001) was designed to be shifted into a perfect competition model or a model that reflects economies of scale or capital accumulation effects controlling related variables. Various forms of simulations using different parameters may be conducted as well. These include cases where GTAP parameters and Korean parameters are used for the first time in a multi-country CGE modeling.

Table 5 presents the impact of bilateral preferential tariff elimination on Korean macroeconomic variables. ${ }^{8}$ The simulation results, whose estimates were based on a new model with economies of scale, capital accumulation effects, and Korean parameters, are significantly different from those reported in the previous study. Firstly, unlike the 2000 KIEP study, the new study indicates that the conclusion of a bilateral FTA will likely improve Korea's GDP in addition to having other extensive effects. In the short-term, Korea's GDP is expected to rise by $0.22-0.33$ per cent, but if capital accumulation accelerates in the mid to long-term, this estimate can reach $0.82-1.90$ per cent.

Furthermore, when economies of scale are modeled, the impact is usually larger regardless of the parameters applied. For example, in the case of long-term effects using GTAP parameters, the GDP growth rate for the constant scale model was estimated to be 0.82 per cent. This figure more than doubles to 1.9 per cent under a scale economy model.

According to simulation results using the GTAP parameter and the Korean parameter, Korea's trade balance will be improved by US\$5-8.3 billion and US\$6.5-9.8 billion, respectively. The calculation done by the Korean parameters is larger because it is relatively less elastic. Korea's trade balance with the world may vary depending on the method of analysis. It is expected to improve in the long term after slightly worsening initially. A Korea-Japan FTA will eventually improve Korea's trade balance with Japan by $\$ 2.2$ billion.

7. Trade, investment, and growth have inter-dynamic functions. See papers by Baldwin (1989), Grossman and Helpman (1991, 1995), and Baldwin and Venables (1995) conducted metrical verifications of the relationship between trade, investment, and growth. Using these relations, dynamic effects can be modeled into a CGE model. Refer to Cheong (2001) for detailed discussion.

8 Although the model used in this study estimates the impact on Japan's economy, the Japanese economy is not taken into consideration since the model itself was centered on the Korean economy. 
Table 5. Economic Impacts of a Korea-Japan FTA on Korea

(\%,\$ billion)

\begin{tabular}{|c|c|c|c|c|c|c|c|c|c|}
\hline & \multirow{3}{*}{$\begin{array}{c}2000 \\
\text { Estinates }\end{array}$} & \multicolumn{4}{|c|}{ GTAP Parameters } & \multicolumn{4}{|c|}{ GTAP + Korean Parameters } \\
\hline & & \multicolumn{2}{|c|}{ Constant Scale } & \multicolumn{2}{|c|}{$\begin{array}{c}\text { Economies of } \\
\text { Scale }\end{array}$} & \multicolumn{2}{|c|}{ Constant Scale } & \multicolumn{2}{|c|}{$\begin{array}{c}\text { Economies of } \\
\text { Scale }\end{array}$} \\
\hline & & $\begin{array}{c}\text { Short } \\
\text { term }\end{array}$ & $\begin{array}{l}\text { Mid to } \\
\text { Long } \\
\text { term }\end{array}$ & $\begin{array}{l}\text { Short } \\
\text { term }\end{array}$ & $\begin{array}{l}\text { Mid to } \\
\text { Long } \\
\text { term }\end{array}$ & $\begin{array}{l}\text { Short } \\
\text { term }\end{array}$ & $\begin{array}{l}\text { Mid to } \\
\text { Long } \\
\text { term }\end{array}$ & $\begin{array}{l}\text { Short } \\
\text { term }\end{array}$ & $\begin{array}{l}\text { Mid to } \\
\text { Long } \\
\text { term }\end{array}$ \\
\hline Real GDP(\%) & -0.07 & 0.22 & 0.82 & 0.30 & 1.90 & 0.21 & 0.96 & 0.33 & 1.79 \\
\hline $\begin{array}{l}\text { Welfare } \\
\text { Level(\%) }\end{array}$ & -0.19 & 0.28 & 0.44 & 0.33 & 1.31 & 0.30 & 0.66 & 0.38 & 1.39 \\
\hline $\begin{array}{l}\text { Changes in } \\
\text { Trade Balance } \\
\text { with Japan }\end{array}$ & -6.09 & -4.3 & -4.2 & -3.6 & -3.6 & -2.7 & -2.6 & -1.9 & -1.9 \\
\hline $\begin{array}{l}\text { Changes in } \\
\text { Global Trade } \\
\text { Balance }\end{array}$ & -15.34 & -0.10 & 0.23 & -0.10 & 0.64 & -0.11 & 0.16 & -0.11 & 0.34 \\
\hline
\end{tabular}

Source: Cheong (2001).

The estimates in Table 5 differ from those reported in the joint FTA study by Korea and Japan in 2000, although the estimates of GDP growth rate and welfare level are similar. However, while the previous study concluded that Korea's trade balance with Japan would decline, this study suggested that the balance would improve. These different results could originate from different assumptions used on liberalization coverage, analysis methodology and data used, but the overall analysis in this study are more reliable.

\section{CONCLUSION}

The concerns of Korea's business sector over the FTA are increasing, as the negotiation with Japan has accelerated since mid-2004. It is known that the two countries are scheduled to start negotiations for tariff concessions in the second half of 2004. The FKI, which had supported a Korea-Japan FTA, is now petitioning the government of Korea to slow the process toward concluding the FTA. Academia and labor unions also have displayed opposition. In mid-May 2004, during the third round of negotiations for a Korea-Japan FTA, the Korean Confederation of Labor Unions (KCFL) physically demonstrated against a Korea-Japan FTA in front of the government complex in Seoul.

The recent growing trend of negative positions against a Korea-Japan FTA seems to be related to the following aspects. Firstly, while business executives delivered pro-FTA positions before the start of negotiations, recognizing economic gains coming from various forms of closer economic cooperation, now trade managers are beginning to show concern over the FTA, focusing on weakening price competitiveness under the FTA and disadvantageous positions in market access. Second, they might deliver strategic comments in order to minimize market liberalization in the FTA, although they accept the 
necessity for the FTA. Third, they may expect government compensation or support for affected industries, as the Korea-Chile FTA did for agriculture. Fourth, generally, opposition to the FTAs may be covered more by the press than support for them.

Some, including the KCFL, argue that the Korea-Japan FTA should be reconsidered. They insist that it is evident that Korea will sustain damages in the short-run and the dynamic (long-term) benefits are still ambiguous and uncertain. On some points, they may be right, but their arguments are incomplete. First of all, in the short term, they estimate that an FTA with Japan will be disadvantageous for Korea due to Japan's strong industrial competitiveness and low tariff rates. However, this argument is based on an across-the-board elimination of tariffs, and there is little possibility that such results occur under the current negotiations, since many sensitive Korean manufacturing sectors will be exempted from trade liberalization. In addition, eliminating tariffs on these sensitive items is to be undertaken over a long period after being included in the liberalization package. Moreover, Korea will not be in a hurry to conclude the FTA with Japan unless there is concrete confidence of balanced economic gains through the FTA between the two countries. As Korea is at a disadvantage in industrial competitiveness, it seems to be taking a cautious approach to preparing a tariff concession proposal for an FTA with Japan based on studies for the estimated damages on sensitive industries in market access for automobiles, machinery and household electronics. Although the mid to long-term dynamic gains are based on economies of scale, adjustment of industrial structure and inflows of foreign direct investment are uncertain in some aspects. However, these economic gains will be eventually determined by Korea's endeavors toward improving its economic and trade rules, fostering a pro-competitive environment, facilitating technological innovation, reducing business costs and developing Korea as FTA hub by concluding a number of FTAs with major trading partners.

Inaccurate estimation of the economic effects of a Korea-Japan FTA has also contributed to the negative perception of the FTA. Existing studies on the FTA bear the following problems. First of all, those studies assumed across-the-board elimination of tariffs. Second, for estimation methods for FTAs, dynamic effects were not appropriately estimated. Third, the opportunity costs of not concluding an FTA with Japan are not considered. Japan is expected to transfer many of its traditional industries to third countries because of a shortage of young workers. If these industries are moved to other developing countries, Korea may be worse off with heightened competition in the world market.

In the meanwhile, as the government of Korea has been promoting FTAs with a number of countries, it might be difficult to concentrate its efforts on a Korea-Japan FTA. Although related governmental ministries such as the Ministry of Foreign Affairs and Trade (MOFAT) and MOCIE reinforced full-time staff for FTA affairs this year, it is still inferior in numbers compared to Japan. Under these circumstances, Korea drastically increased the number of FTAs negotiated. According to the FTA promotion roadmap set by the government of Korea (MOFAT 2004), the country will actively promote bilateral FTAs with Mexico, ASEAN and EFTA next year, implementing a strategy for plural 
FTAs step by step. In particular, the FTA joint study with ASEAN will end within 2004, and official negotiations are expected to begin at the end of this year. The negotiation for an FTA with Mexico will also see rapid progress. The working level talks will begin from September 2004, and an official joint study will start next year.

The governments of both Korea and Japan agreed to endeavor in concluding negotiations for a bilateral FTA by the end of 2005, but there are still doubts as to whether both countries can reach an agreement. Above all, market access will be the most difficult issue for the negotiation. Although Japan insists on the complete market opening, it still put an emphasis on the exemption on agricultural products. Moreover, it will be difficult to set up preferential rules of origin. As industries overlap and are competitive between the two countries, it is not a simple matter for companies from both countries to determine desirable rules of origin. It is expected that it will be difficult for the Korean government to persuade labor unions and NGOs that are against an FTA with Japan. Furthermore, as the negotiations progress, public opposition toward an FTA with Japan will expand rather than turn supportive. Overall, it is expected to take at least more than two years to conclude an FTA with Japan.

\section{REFERENCES}

Baldwin, Richard E. 1989, “The growth effects of 1992,” Economic Policy 4, 247-283.

Bergsten, C. Fred. 2000, “The New Asian Challenge.” Institute for International Economics (IIE) Working Paper 00-4, Institute for International Economics, Washington D. C.

Booz, Allen and Hamilton, 1997, Revitalizing the Korean Economy towards the $21^{s t}$ Century, Report for Vision Korea Committee, Booz-Allen-Hamilton Inc.

Cheong Inkyo, 1998, "Economic Effects of the Korea-Japan FTA.” Unpublished manuscripts, Korea Institute for International Economic Policy, Seoul (in Korean).

Cheong Inkyo, 1999a, "A Study on the Feasibility of Economic Integration in Northeast Asia." Unpublished paper presented at the international conference of The Road to Greater Northeast Asian Economic Cooperation in the $21^{\text {st }}$ Century held in Seoul. October.

Cheong, Inkyo, 1999b, "Economic Integration in Northeast Asia: Searching for a Feasible Approach." Unpublished paper presented at the annual conference of the Japanese Society of International Economics. Osaka Sankyo University. November.

Cheong, Inkyo, 2001, The Economic Effects of a Korea-Japan FTA, KIEP Policy Paper 01-04, Korea Institute for International Economic Policy, Seoul. 
Federation of Korean Industries (FKI). 2001, "Korea Industries' Perception of an FTA," Seoul. The Federation of Korean Industries (in Korean).

Frankel, J. A., Stein, E. and Wei, S.J., 1997, "Continental Trading Blocs: Are They Natural or Supernatural?" In Jeffrey A. Frankel, ed. The Regionalization of the World Economy, University of Chicago Press, Chicago.

Grossman, G.M. and Helpman, E., 1991, Innovation and Growth in the Global Economy, MIT Press, Cambridge, MA.

Grossman, G.M. and Helpman, E., 1995, "Technology and trade," Centre for Economic Policy Research Discussion Paper No. 1134.

Korea Institute for International Economic Policy (KIEP), 2001, "Analysis of Factors and Changes in Korea's Export Competitiveness,” Internal Report.

KIEP and Institute for Developing Economies (IDE), 2000, "Toward a Korea-Japan FTA: Assessment and Prospects, Unpublished paper presented at an international seminar Towards Closer Korea-Japan Economic Relations: Proposal for Formulating a $21^{\text {st }}$ Century Partnership," Shilla Hotel, Seoul.

Kim, Heungchong, 2002, "Has Trade Intensity in ASEAN+3 Really Increased? Evidence from a Gravity Analysis,” KIEP Working Paper 02-12, Korea Institute for International Economic Policy, Seoul.

Kimura, Fukunari and Ando Mitsuyo, 2003, "Intra-regional trade among China, Japan, and Korea: Intra-industry trade of major industries," in Yangseon Kim and Chang Jae Lee (eds.), Northeast Asian Economic Integration: Prospects for a Northeast Asian FTA, Korea Institute for International Economic Policy, Seoul.

Lee, Chang-Soo and Soon-Chan Park, 2002, "An Examination of the Formation of Natural Trading Blocs in East Asia," KIEP Working Paper 02-13, Korea Institute for International Economic Policy, Seoul.

Levine, R. and Renelt, D., 1992, “A sensitivity analysis of cross-country growth regressions,” The American Economic Review 82(4), 942-963.

McKibbin, Warwick J., Lee Jong-Wha and Cheong Inkyo, 2002, "A Dynamic Analysis of The Korea-Japan Free Trade Area: Simulations with the G-Cubed Asia-Pacific Model," KIEP Working Paper 02-09, Korea Institute for International Economic Policy, Seoul.

Ministry of Commerce, Industry and Energy (MOCIE), 2004, "Korea's Terms of Trade: Yearly Statistics." (in Korean.) www.mocie.go.kr 
Ministry of Foreign Affairs and Trade (MOFAT). 2004, "Ministerial Meeting on International Economies." May 10 (in Korean)

www.mofat.go.kr/ko/news/

Nakjima, T., and Kwon. O.K., 2001, "An Analysis of the Economic Effects of JapanKorea FTA," ERINA Discussion Paper No. 0101e, Economic Research Institute for Northeast Asia, Niigata, Japan.

Scollay, Robert and Gilbert. John P., 2001, New Regional Trading Arrangements in the Asia Pacific, Institute for International Economics Washington, D.C.

Sohn, Chan-Hyun and Yoon Jinna, 2001, "Does the Gravity Model Fit Korea's Trade Pattern? - Implications for Korea's FTA Policy and North-South Korean Trade," KIEP Working Paper 01-01, Korea Institute for International Economic Policy, Seoul. 